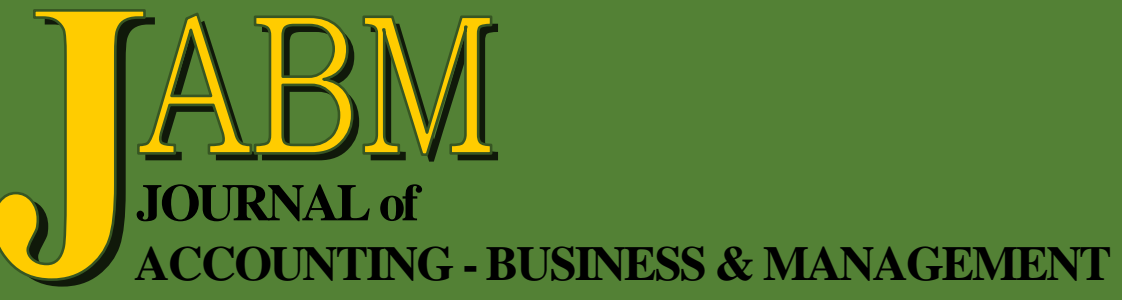

The Relationship between the Ownership Structure, Capital Structure and Performance

Ali Al-Thuneibat

The Effect of Self Efficacy and Information Quality on Behavioral Intention with Perceived Usefulness as Intervening Variable

Muslichah

Empirical Analysis of Factors Influencing Use of Internet on Ships

A. S. Saravanan, Jayalakshmy Ramachandran, A. Seetharaman, Karripur Nanda Kumar, and Capt. Kailash C. Joshi

Pawnshops Regulatory Environment: A Readability Analysis

Geralyn Miller, Steven A. Hanke, and Hui Di

Auditor Litigation and the Penalties on U.S. Client Firms after the Private Securities Litigation Reform Act

Nana Y. Amoah, Anthony Anderson, Isaac Bonaparte and Kyle Meyer 
Journal of Accounting - Business \& Management vol. 25 no. 1 (2018) 35-49

\title{
Empirical Analysis of Factors Influencing Use of Internet on Ships
}

\author{
A. S. Saravanan* \\ Jayalakshmy Ramachandrant \\ A. Seetharaman \\ Karripur Nanda Kumar $₫$ \\ Capt. Kailash C. Joshi*
}

\begin{abstract}
The purpose of this study was to evaluate the factors influencing the emergence of internet on ships and the resultant cost. Data collected from 255 respondents, mainly seafarers (captain and officers) and shore-based ship managers revealed that emergence of the internet on ships is influenced by perceived usefulness, organisation readiness, external pressure and technology penetration. It is also witnessed that cost of internet on ships has an effect on the penetration of the internet and new technology. The emergence of the internet on ships provides an effective communication link with all stakeholders of the ship, enhances safety and security with real time data on cargo, incidents, piracy, terrorism and weather conditions. It facilitates timely delivery of stores and spare parts for ship repairs and maintenance, thus providing immense satisfaction to all stakeholders. It thus has a significant impact on the industry.
\end{abstract}

Keywords: cargo ships, communication, external pressure, internet, innovation, stakeholders.

\section{INTRODUCTION}

The invention of the internet has led to a marked revolution, not only with how people communicate but also how technologies communicate with each other, in this age of digital information flow (Blum, 2012; Tian et. al. 2017). There are several applications on board ship that require communication bandwidth (Wansink \& Stahl, 2017) such as delivery of electronic charts and updates to chart's library, advanced weather and route planning, remote maintenance, infrared scanning of machineries for preventative maintenance (Salva et al., 2004), e-commerce (Szakonyi, 2012), engine and cargo monitoring, using big data/internet of things/data mining (Dale, 2014), in order to increase vessel performance, carry out preventive maintenance, crew calling and crew internet, e-learning, delivering of licensed entertainment for crew, regulatory compliance, online prediction of ship rolling motion (Lin \& Wang, 2013) etc. However,

\footnotetext{
* Senior Lecturer, Taylors University. No. 1 Jalan Taylor's, 47500 Subang Jaya, Selangor Darul Ehsan, Malaysia. E-mail: saravanabavashiva@gmail.com.

† Asst. Professor, Nottingham University Business School. The Nottingham University in Malaysia. Jalan Broga, 43500 Semenyih. Tel: +(603) 89248779. E-mail: jayalakshmy.rama @ nottingham.edu.my.

\#Dean Academic Affairs, S. P. Jain School of Global Management. 10 Hyderabad Road, Singapore-119579. Tel: +6562704748 Ext. 106. E-mail: seetha.raman@spjain.org.

$\S$ Associate Professor, S. P. Jain School of Global Management. 10 Hyderabad Road, Singapore 119579. E-mail: Kumar.karippurnanda@spjain.org.

*** Post Graduate Scholar, S. P. Jain School of Global Management. 10 Hyderabad Road, Singapore-119579. E-mail: Kcjoshi71@yahoo.com.
} 
it was surprising to learn that in late 2013 , only $12 \%$ of seafarers on cargo ships had freely available internet access and two-thirds had none at all (Nusca, 2014). This study and research therefore focuses on the "emergence of the internet on ships" and the factors influencing and associated with it. Our contributions are very significant as in highlighting the importance to internet to a wide range of stakeholders for effective communication to avoid tragedies during times of emergencies in marine life.

\section{LITERATURE REVIEW AND RESEARCH FRAMEWORK}

\subsection{Cost of Internet on Ships}

It was always costly to acquire valuable information (Kachwamba \& Saebø, 2012; Kim et al., 2004). However, over the years, internet connection on ships which previously cost as much as 95 cents a minute, is now available below 50 cents per minute, and is expected to come down further with innovation in technologies.

$\mathbf{H}_{1}$ : the higher cost of the internet on ships is detrimental to the emergence of the internet on ships.

Previous studies have proven that using internet provides a huge reduction in the cost of copying and transmitting large amount of information with improved efficiency and viability (Bullmore et al., 2000; Hutter, 2001; Addison \& Heshmati, 2003; Jaiswal \& Raghav, 2004; and Hongzhuan, et. al., 2013). However, higher internet cost discourages companies from introducing several products and services through internet thus affecting the penetration of technology and internet. The SEM model (Figure 1) shows the path coefficient for individual constructs.

$\mathbf{H}_{2}$ : the cost of the internet affects penetration of the internet on ships.

Figure 1

Cost of Internet

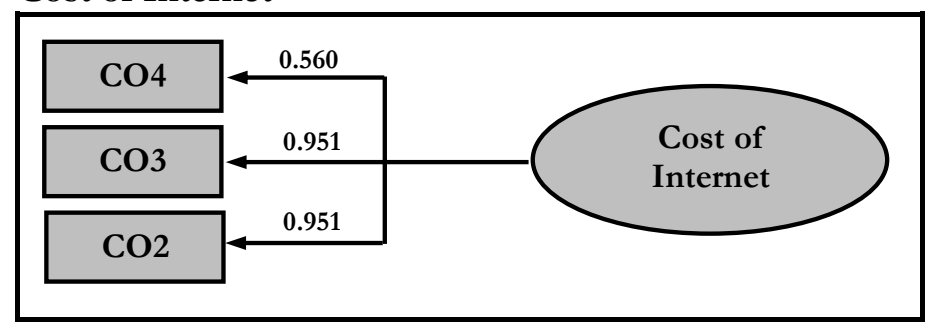

\subsection{Penetration of Internet}

There is sufficient evidence indicating that income, human capital, youth dependency ratio, tele density, quality and development of a sector are associated with penetration rates for any technology including the Internet on ships (DiMaggio \& Hargittai, 2001; Kiiski \& Pohjola, 2002; Yang \& Jun, 2002; and Chinn \& Fairlie, 2010). Additionally, the performance of the mobile internet can be impacted by multiple factors including websites, devices, and network components but with constant changes in these factors, as well as complexity of network, it is extremely difficult to identify root causes (Amrutkar et al., 2013). Therefore, as more and more new shipboard technologies and applications are using the internet, this will certainly increase penetration and further enhance the emergence of internet on ships despite the higher cost (Stein et al., 2007; Solaymani et al., 2012). The SEM model (Figure 2) shows that the path coefficient for individual constructs

$\mathbf{H}_{3}$ : penetration of technology and internet creates emergence of the internet on ships. 
Figure 2

Penetration of Internet

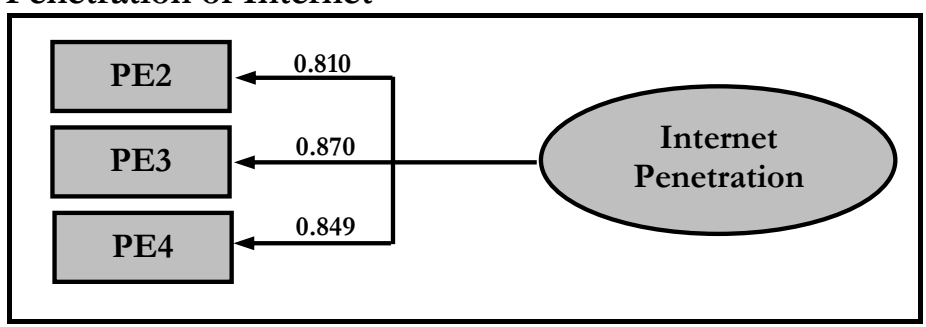

\subsection{Organisation Readiness}

It is necessary that organisations provide sufficient infrastructure keeping in mind that larger firms usually have multiple levels of bureaucracy that can deter decision-making processes especially for new ideas, services and projects (Oliveira \& Martins., 2010; Ramdani, et. al 2013). It is established that the internet provides a "universal" channel for information and communication (I\&C) flows (Nusca, 2014). The ROI should be evaluated carefully since organisational readiness is affected by various factors such as technological infrastructure and competence, expected absolute returns with due considerations to associated challenges, firm size and ownership structure (Aboelmaged, 2014; Yang et. al., 2015). The path coefficient in Figure 3 shows the values of the individual constructs.

$\mathbf{H}_{4}$ : organisational readiness directly affects emergence of the internet on ships.

Figure 3

Organisation Readiness

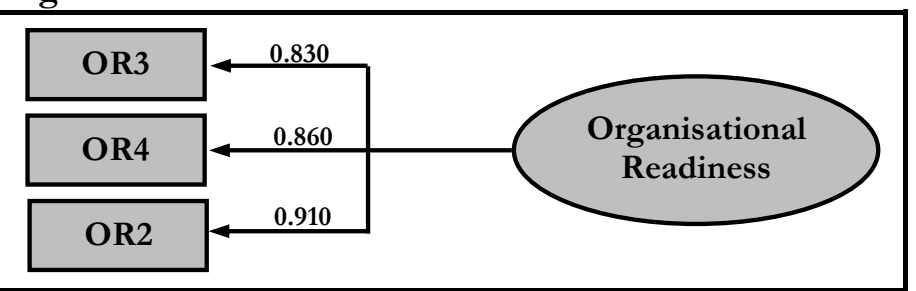

\subsection{External Pressure}

In most countries, regulatory agencies are charged with the supervision of communication activities but the net content is often provided by private contracts under different jurisdiction (Porter \& Millar, 1985; Hutter, 2001). Seafarers' unions coordinate with ship owners to improve seafarers' living standards on board ships. Empirical evidence from research already suggests that external pressure is a powerful driver of IT adoption and diffusion (Iacovou et al., 1995; Mehrtens et al., 2001; Zhu et al., 2003; Dholakia \& Kshetri, 2004; Gibbs \& Kraemer, 2004; Grandon \& Pearson, 2004; Hollenstein, 2004; Al-Qirim, 2007; Battisti et al., 2007; Lai et al. 2007; and Oliveira \& Martins, 2010). The path coefficient is provided in Figure 4

$\mathbf{H}_{5}$ : external pressure enhances emergence of the internet on ships.

Figure 4

External Pressure

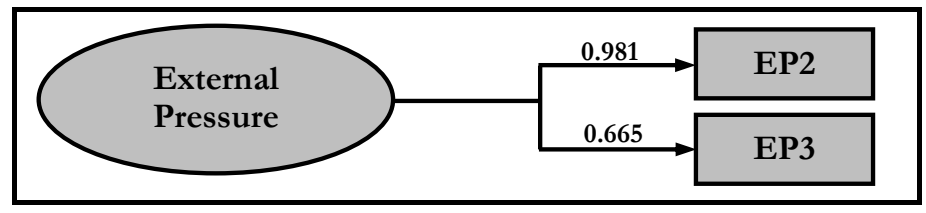




\subsection{Perceived Usefulness}

Several conceptual models have been projected to explain end-user acceptance behaviour (Davis, 1989; Ma \& Lui, 2004). In Technology Acceptance Model, Davis (1989) proposed two determinants of computer acceptance: perceived usefulness (PU) and perceived ease of use (PEOU). If managers are able to understand the relative advantage of an innovation then it increases the prospect for allocation of necessary managerial, financial, and technological resources (Iacovou et al., 1995). Other empirical studies also validate that if perception of the benefits of an innovation is positive then it provides an incentive for using that innovation (Grover \& Teng, 1994; Premkumar et al., 1994; Iacovou et al., 1995; Kuan \& Chau, 2001; Gibbs \& Kraemer, 2004; Son et al., 2005; Hsu et al., 2006; and Lin \& Lin, 2008). Past research suggest that the modern communication and social media networking are important for crews in the ship while sailing to ensure better security and stay connected throughout with the staff in the ports (Salva et. al, 2004; Lin \& Wang, 2013; Dale 2014; and Nusca, 2014). Such modern communication methods will eventually motivate seafarer, especially the younger generation, to choose and develop their career at sea. The path model and coefficients are demonstrated in Figure 5.

$\mathbf{H}_{6}$ : perceived usefulness has a significant direct impact on the emergence of the internet on ships.

Figure 5

Perceived Usefulness

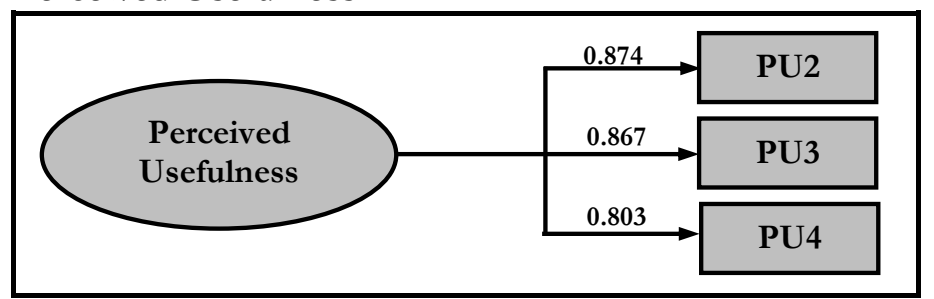

\subsection{Emergence of Internet on Ships (Dependent Variable)}

The Emergence of the Internet on Ships is the dependant variable in this research which responds to independent variables discussed in the earlier sections. The path coefficient (Figure 6) for all these measures is well above 0.8, which demonstrates strong measures (Bullmore et al., 2000).

\section{Figure 6}

\section{Emergence of Internet in Ships}

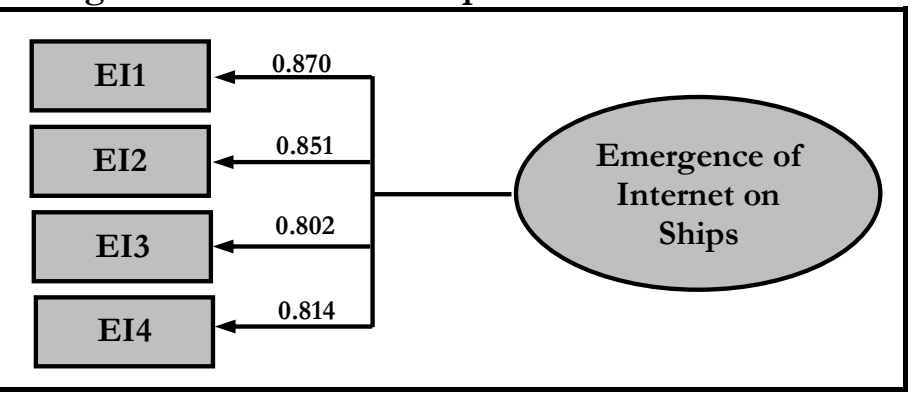

\section{RESEARCH METHODOLOGY}

The research predominantly used primary data through online survey of a sample of those working on ships and shipping industry. The relationship between the dependent and independent variables is depicted in Figure 7. 
Figure 7

Diagrammatic Representation

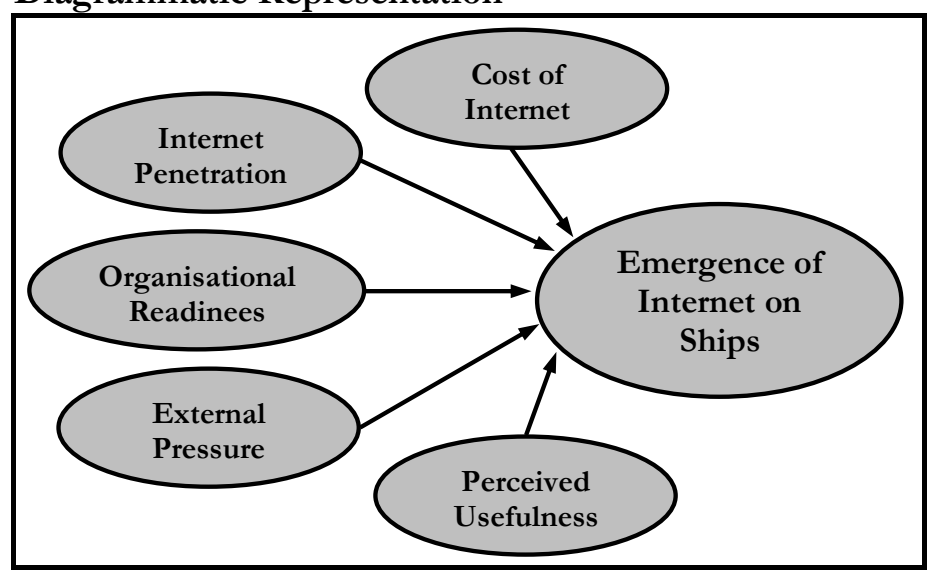

The questionnaire was prepared using "Google Forms". An email and WhatsApp invitation was sent out to shipping professionals and ship board personnel (seafarers) to complete the online survey questionnaire, which was used in the collection of primary data. Table 1 shows a summary of the proposed indicators and variables that were prepared after researching related articles and literature.

Table 1

Summary of the Proposed Indicators and Variables

\begin{tabular}{|c|c|c|c|}
\hline $\begin{array}{l}\text { Ques. } \\
\text { No. }\end{array}$ & Indicator & $\begin{array}{l}\text { Reference } \\
\text { Literature }\end{array}$ & $\begin{array}{l}\text { Related to } \\
\text { Variables }\end{array}$ \\
\hline 1. & Higher cost of the internet & $\begin{array}{l}\text { Kachwamba and Saebo (2012), } \\
\text { Kim et al. (2004) }\end{array}$ & \multirow{3}{*}{$\begin{array}{l}\text { Cost of the } \\
\text { internet on } \\
\text { ships }\end{array}$} \\
\hline 2. & $\begin{array}{l}\text { Unlimited broadband at } \\
\text { fixed monthly fees }\end{array}$ & Hongzhuan et al. (2013) & \\
\hline 3. & $\begin{array}{l}\text { Product and services via } \\
\text { internet }\end{array}$ & $\begin{array}{l}\text { Hongzhuan et al. (2013), Hutter } \\
\text { (2001) }\end{array}$ & \\
\hline 4. & $\begin{array}{l}\text { Restricted and limited } \\
\text { internet availability on } \\
\text { ships }\end{array}$ & Chinn and Fairlie (2010) & \multirow{3}{*}{$\begin{array}{l}\text { Penetration of } \\
\text { the internet on } \\
\text { ships }\end{array}$} \\
\hline 5. & Slow internet speed & Yang and Jun (2002) & \\
\hline 6. & $\begin{array}{l}\text { Interrupted network } \\
\text { coverage }\end{array}$ & Amrutkar et al. (2013) & \\
\hline 7. & $\begin{array}{l}\text { Real time data through the } \\
\text { internet }\end{array}$ & Nusca (2014) & \multirow{3}{*}{$\begin{array}{l}\text { Organizational } \\
\text { readiness }\end{array}$} \\
\hline 8. & $\begin{array}{l}\text { Returns on investment } \\
\text { (ROI) }\end{array}$ & Aboelmaged (2014) & \\
\hline 9. & Operational sustainability & Yang et a. (2015) & \\
\hline $\begin{array}{l}10 . \\
11\end{array}$ & Regulations & Hutter (2001) & $\begin{array}{l}\text { External } \\
\text { pressure } \\
\end{array}$ \\
\hline $\begin{array}{l}12 . \\
13 . \\
14 .\end{array}$ & $\begin{array}{l}\text { Customer value } \\
\text { Security \& safety } \\
\text { Crew welfare } \\
\end{array}$ & $\begin{array}{l}\text { Dale (2014) } \\
\text { Gaul Jr. (2001) } \\
\text { Nusca (2014) }\end{array}$ & $\begin{array}{l}\text { Perceived } \\
\text { usefulness }\end{array}$ \\
\hline $\begin{array}{l}15 . \\
16 . \\
17 . \\
18 .\end{array}$ & $\begin{array}{l}\text { Effective communication } \\
\text { Safety of ships } \\
\text { Satisfaction of stakeholders } \\
\text { Timely delivery of goods }\end{array}$ & $\begin{array}{l}\text { Blum (2012), Nusca (2014) } \\
\text { Field (2011), Nusca (2014) } \\
\text { Lu et al. (2006) } \\
\text { Tirschwell (2004), Szakonji } \\
\text { (2012) }\end{array}$ & $\begin{array}{l}\text { Emergence of } \\
\text { the internet }\end{array}$ \\
\hline
\end{tabular}


Pre-testing of the questionnaire was carried out with a sample of 30 industry participants who had expertise and several years of experience using and implementing internet on ships. After receiving feedback from participants and personal interviews with some of the experts, namely VPs and directors of leading organisations in Singapore and abroad, the questionnaire form was further developed. The final questionnaire contained five measures for the five independent variables and two to four questions to measure each of the dependent variables. A five-point Likert scale was used to measure the indicators (anchored at $1=$ strongly disagree and $5=$ strongly agree). The respondents chosen were mainly seafarers (officers) working on merchant ships of various types and presently using the internet on ships, as well as ship managers responsible for the management of ships including installing and regulating internet on ships. These respondents were employees of multinational shipping companies with a global presence. The email invitation with the questionnaire was sent to more than 1000 seafarers and over 100 shore-based shipping professionals with a seafaring background. 255 professionals $(23.2 \%)$ responded. All responses were complete and used for the final data set.

\section{RESULTS AND ANALYSIS}

Participants were categorised with their present roles as can be seen in below in Table 2.

\section{Table 2}

Demographic Characteristics of Respondents Survey participants $(n=255)$

\begin{tabular}{lrr}
\hline Position: & & \\
Ship Management & 61 & $31.8 \%$ \\
Ship Captain & 62 & $24.3 \%$ \\
Ship Officers & 47 & $18.4 \%$ \\
Ship Engineers & 40 & $15.7 \%$ \\
Others & 25 & $9.8 \%$ \\
\hline Role on Internet on Ship: & & \\
User (on Ship) & 166 & $65.1 \%$ \\
Observer (on Shore) & 83 & $32.5 \%$ \\
Implementer (Service Provider) & 6 & $2.4 \%$ \\
\hline Ship Type: & & \\
Tankers & 203 & $79.6 \%$ \\
Bulkers & 26 & $10.2 \%$ \\
Containers & 13 & $5.1 \%$ \\
Off-shore & 7 & $2.7 \%$ \\
Others & 6 & $2.4 \%$ \\
\hline
\end{tabular}

Data collected through the primary research (online survey) method were analysed using ADANCO 2.0, a software for variance-based structural equation modelling (Furrer et al., 2012). ADANCO uses a composite modelling approach to test hypotheses, which has the advantage of not imposing normality conditions on the data (Gefen et al., 1987). The analysis was performed in two steps: in the first step, the quality of the structural model was estimated; in the second step, the reliability and validity were measured to determine the best model fit, path analysis was undertaken and the model parameters were estimated (Zikmund, 2003). Cronbach's alpha was used to determine the reliability of this model (Bacon et al., 1995; Dijkstra \& Henseler, 2015a). A construct reliability of 0.7 is also required (Nunnally \& Bernstein 1994). The reliability measure which is most important for PLS is @A (Dijkstra \& Henseler, 2015b); 
currently, it is the only consistent reliability measure for PLS construct scores. Statistics for each construct are given in Table 3.

Table 3

Overall Reliability of the Constructs

\begin{tabular}{lcccc}
\hline \multicolumn{1}{c}{ Construct } & $\mathbf{R}^{2}$ & $\begin{array}{c}\text { Dijkstra-Henseier's } \\
\text { Rho (@A) (Construct } \\
\text { Reliability) }\end{array}$ & $\begin{array}{c}\text { Cronbach's } \\
\text { Alpha }(\boldsymbol{\alpha})\end{array}$ & $\begin{array}{c}\text { Average } \\
\text { Variance } \\
\text { Extracted } \\
\text { (AVE) }\end{array}$ \\
\hline $\begin{array}{l}\text { Emergence of the } \\
\text { Internet on Ships }\end{array}$ & 0.640 & 0.8578 & 0.8544 & 0.6965 \\
Cost of the Internet & 0.9241 & 0.7665 & 0.7081 \\
Penetration & 0.8044 & 0.7972 & 0.7113 \\
Org. Readiness & 0.8697 & 0.8369 & 0.7525 \\
External Pressure & 1.6724 & 0.6726 & 0.7018 \\
Perceived Usefulness & 0.8094 & 0.8047 & 0.7197 \\
\hline
\end{tabular}

The dominant measure of convergent validity is the average variance extracted (AVE) (Fornell \& Larcker, 1981). AVE of 0.5 or higher is therefore regarded as acceptable. For each construct, the average variance extracted (AVE) should be greater than 0.5 (Chin, 1998).

Table 4 shows the minimum AVE value is 0.6965 hence the research model satisfies the measurement requirements while Table 5 shows that the model has discriminant validity.

Table 4

Construct Validity

\begin{tabular}{lc}
\hline \multicolumn{1}{c}{ Construct } & Average Variance Extracted (AVE) \\
\hline Emergence of the Internet on Ships & 0.6965 \\
Cost of the Internet & 0.7081 \\
Penetration & 0.7113 \\
Organisation Readiness & 0.7525 \\
External Pressure & 0.7018 \\
Perceived Usefulness & 0.7197 \\
\hline
\end{tabular}

Table 5

Discriminant Validity

\begin{tabular}{lcccccc}
\hline \multicolumn{1}{c}{ Construct } & $\begin{array}{c}\text { Emergence } \\
\text { of the Inter- } \\
\text { net on ships }\end{array}$ & $\begin{array}{c}\text { Cost of } \\
\text { the } \\
\text { Internet }\end{array}$ & $\begin{array}{c}\text { Penetra } \\
\text {-tion }\end{array}$ & $\begin{array}{c}\text { Organisa- } \\
\text { tion } \\
\text { Readiness }\end{array}$ & $\begin{array}{c}\text { External } \\
\text { Press- } \\
\text { ure }\end{array}$ & $\begin{array}{c}\text { Perceived } \\
\text { Usefulness }\end{array}$ \\
\hline $\begin{array}{l}\text { Emergence of } \\
\text { the Internet on } \\
\text { Ships }\end{array}$ & $\mathbf{0 . 6 9 6 5}$ & & & & & \\
$\begin{array}{l}\text { Cost of the } \\
\text { Internet }\end{array}$ & 0.0322 & $\mathbf{0 . 7 0 8 1}$ & & & & \\
$\begin{array}{l}\text { Penetration } \\
\begin{array}{l}\text { Organisation } \\
\text { Readiness }\end{array}\end{array}$ & 0.0334 & 0.0593 & $\mathbf{0 . 7 1 1 3}$ & & & \\
$\begin{array}{l}\text { External } \\
\text { Pressure }\end{array}$ & 0.2671 & 0.0880 & 0.0115 & $\mathbf{0 . 7 5 2 5}$ & & \\
$\begin{array}{l}\text { Perceived } \\
\text { Usefulness }\end{array}$ & 0.0593 & 0.0017 & 0.0086 & 0.0000 & $\mathbf{0 . 7 0 1 8}$ & \\
\hline
\end{tabular}

Notes: squared correlations; AVE on the diagonal. 
In terms of model fit, it would indicate poor validity for a value of 0 but residual values of between 0.05 and 0.08 for SRMR (Standardised Root Mean Square Residual) indicates a reasonable level of approximation error (Steiger et al., 1985).

Tables 6 and 7 show the standardised root mean square residual (SRMR) values of the saturated and estimated models respectively. All these values are within the cutoff of 0.08 .

Table 6

Saturated Model

\begin{tabular}{lccc}
\hline & Value & HI95 & HI99 \\
\hline SRMR & 0.0689 & 0.0661 & 0.0876 \\
dULS $_{\text {UL }}$ & 0.8115 & 0.7473 & 1.3124 \\
d $_{\mathbf{G}}$ & 0.4998 & 0.9400 & 1.2640 \\
\hline
\end{tabular}

Table 7

Estimated Model

\begin{tabular}{llll}
\hline & Value & HI95 & HI99 \\
\hline SRSR & 0.0749 & 0.0787 & 0.0944 \\
dULS $_{\text {U }}$ & 0.9592 & 1.0579 & 1.5254 \\
dG & 0.5016 & 0.9461 & 1.2674 \\
\hline
\end{tabular}

It is possible to use bootstrapping methods (Efron, 1990) for structural equation modelling (SEM) in ADANCO 2.0 with an unknown population. The test for level of significance is done using t-statistic values.

The levels of significance in p-values and t-values (Meinshausen \& Rice, 2006) are given in Table 8. Five hypotheses were tested in this research and the outcomes were verified against the t-values, as shown below in Table 9.

Table 8

Significance Levels

\begin{tabular}{ccc}
\hline & Significance & t-value \\
\hline \multirow{2}{*}{ Level of } & $\mathrm{p}<0.1$ & 1.65 \\
significance & $\mathrm{p}<0.05$ & 1.96 \\
& $\mathrm{p}<0.01$ & 2.59 \\
\hline
\end{tabular}

\section{DISCUSSION}

$\mathbf{H}_{1}$ : as can be observed, $\mathrm{H}_{1}(\beta=-0.0146, \mathrm{p}>0.1)$ is not supported. This could be attributed to the fact that demand for the internet on ships is rising irrespective of cost. During the survey, a diverse response was received with regards the cost of the Internet on ships. Seafarers believed there is a high demand for the Internet on ships and present cost of internet does not deter them from using the Internet. However, shore managers were mostly of the opinion that the cost of the Internet on ships is high. This indicates a varying perception exists between the two categories, which could be attributed to the fact that the cost of communication on ships was always higher even before the arrival of the Internet. Even though the cost of the internet on ships is high it can provide seafarers a value for their money.

$\mathbf{H}_{2}$ : the analysis of data found that internet cost has a significant impact on penetration of the internet ( $\mathrm{t}$-value $=2.6357, \mathrm{CI}>99 \%)$ and thus $\mathrm{H}_{2}(\beta=0.0758, \mathrm{p}>0.1)$. This indicates that the cost of the internet makes a significant contribution to the penetration of technology and the internet on ships. This also supports findings from earlier studies indicating that income hence cost are associated with 
technology penetration rates (Chinn \& Fairlie, 2010) and if firms are faced with a low level of internet costs for any work, their motivation to introduce various products and services via the internet increases (Solaymani et al., 2012).

$\mathbf{H}_{3}$ : the analysis shows that the effect of penetration was insignificant $(\mathrm{t}$-value $=1.4761$, $\mathrm{CI}>90 \%)$ for the emergence of the internet on ships. Hence, $\mathrm{H}_{3}(\beta=0.2571)$ was found to be not supported. This result indicates that the demand for the internet on ships is already high even though the quality and availability of the internet on ships is inferior and needs to be improved.

$\mathbf{H}_{4}$ : the fourth hypothesis, tested the effects of organisational readiness on emergence of the Internet and the analysis results show a significant impact ( $\mathrm{t}$-value $=3.7464$, $\mathrm{CI}>99 \%) . \mathrm{H}_{4} \quad(\beta=0.2166, \mathrm{p}<0.01)$ is supported indicating that organisation readiness has a significant impact on the emergence of the internet on ships. This also supports an earlier study that found the technology, organisation and environment (TOE) model is a robust tool to predict if an organisation will adopt technology (Ramdani et al., 2013).

$\mathbf{H}_{5}$ : this study found that the effect of external pressure is significant ( $\mathrm{t}$-value $=3.4592$, $\mathrm{CI}>99 \%)$ and supports $\mathrm{H} 5(\beta=0.1570, \mathrm{p}<0.01)$. This indicates that external pressure, such as from competitors, regulators and unions has a significant effect on the emergence of the internet on ships. This is in sync with earlier studies and empirical evidence suggesting that external pressure is a powerful driver of IT adoption and diffusion (Iacovou et al., 1995; Mehrtens et al., 2001; Zhu et al., 2003; Dholakia \& Kshetri, 2004; Gibbs \& Kraemer, 2004; Grandon \& Pearson, 2004; Hollenstein, 2004; Al-Qirim, 2007; Battisti et al., 2007; Lai et al., 2007; and Oliveira \& Martins, 2010).

$\mathbf{H}_{6}$ : this study found that perceived usefulness had the most significant effect on the emergence of the internet on ships ( $\mathrm{t}$-value $=9.2834, \mathrm{CI}>99 \%)$. Therefore, $\mathrm{H}_{6}$ $(\beta=0.6250, p<0.01)$ is supported. This result clearly indicates that the emergence of the Internet on ships significantly depends on the perceived usefulness and will grow further as more and more useful products are introduced. This study confirms that better managerial understanding of the relative advantage of an innovation certainly increases the likelihood of the allocation of the managerial, financial, and technological resources necessary to use that innovation (Iacovou et al., 1995; Rogers, 2003). These results are in sync with other empirical results validating that positive perception of the benefits of an innovation provides an incentive for its use (Grover \& Teng, 1994; Premkumar et al., 1994; Iacovou et al., 1995; Beatty et al., 2001; Kuan \& Chau, 2001; Gibbs \& Kraemer, 2004; Son et al., 2005; Hsu et al., 2006; and Lin \& Lin, 2008).

The research findings when compared with the hypotheses mainly support and supplement contributions from the existing studies and literatures. This is illustrated by the results of the bootstrapped structural model shown below in Figure 8, together with the path coefficients depicting the correlations between the independent and dependent variables. 
Table 9

Hypothesis Testing Results

\begin{tabular}{|c|c|c|c|c|c|c|}
\hline $\begin{array}{l}\text { Hypo- } \\
\text { thesis }\end{array}$ & Effect & $\begin{array}{c}\text { Path } \\
\text { Coef. }(\beta)\end{array}$ & $\begin{array}{l}\text { Mean } \\
\text { Value }\end{array}$ & $\begin{array}{l}\text { Standard } \\
\text { Error }\end{array}$ & $\begin{array}{c}\mathrm{t}- \\
\text { value }\end{array}$ & $\begin{array}{l}\text { Sup- } \\
\text { ported }\end{array}$ \\
\hline $\mathbf{H}_{1}$ & $\begin{array}{l}\text { Cost of Internet } \rightarrow \\
\text { Emergence of the } \\
\text { Internet on Ships }\end{array}$ & -0.0146 & 0.0096 & 0.0479 & 0.0911 & $\mathrm{NO}$ \\
\hline $\mathbf{H}_{2}$ & $\begin{array}{l}\text { Ships' cost of Internet } \\
\rightarrow \text { Penetration }\end{array}$ & $0.2436^{* *}$ & 0.2625 & 0.0924 & 2.6357 & YES \\
\hline $\mathbf{H}_{3}$ & $\begin{array}{l}\text { Penetration } \rightarrow \\
\text { Emergence of the } \\
\text { Internet on Ships }\end{array}$ & 0.0758 & 0.0785 & 0.0513 & 1.4761 & $\mathrm{NO}$ \\
\hline $\mathbf{H}_{4}$ & $\begin{array}{l}\text { Org. Readiness } \rightarrow \\
\text { Emergence of the } \\
\text { Internet on Ships }\end{array}$ & $0.2166^{* *}$ & 0.2216 & 0.0578 & 3.7464 & YES \\
\hline $\mathbf{H}_{5}$ & $\begin{array}{l}\text { External Pressure } \rightarrow \\
\text { Emergence of the } \\
\text { Internet on Ships }\end{array}$ & $0.1570 * *$ & 0.1594 & 0.0454 & 3.4592 & YES \\
\hline $\mathbf{H}_{6}$ & $\begin{array}{l}\text { Perceived } \\
\text { Usefulness } \rightarrow \\
\text { Emergence of the } \\
\text { Internet on Ships }\end{array}$ & $0.6250^{* *}$ & 0.6152 & 0.0673 & 9.2834 & YES \\
\hline
\end{tabular}

Notes: ** indicates $99.99 \%$ significance.

Figure 8

Structural Equation Modelling (Graphical Representation).

Bootstrapped Structural Model

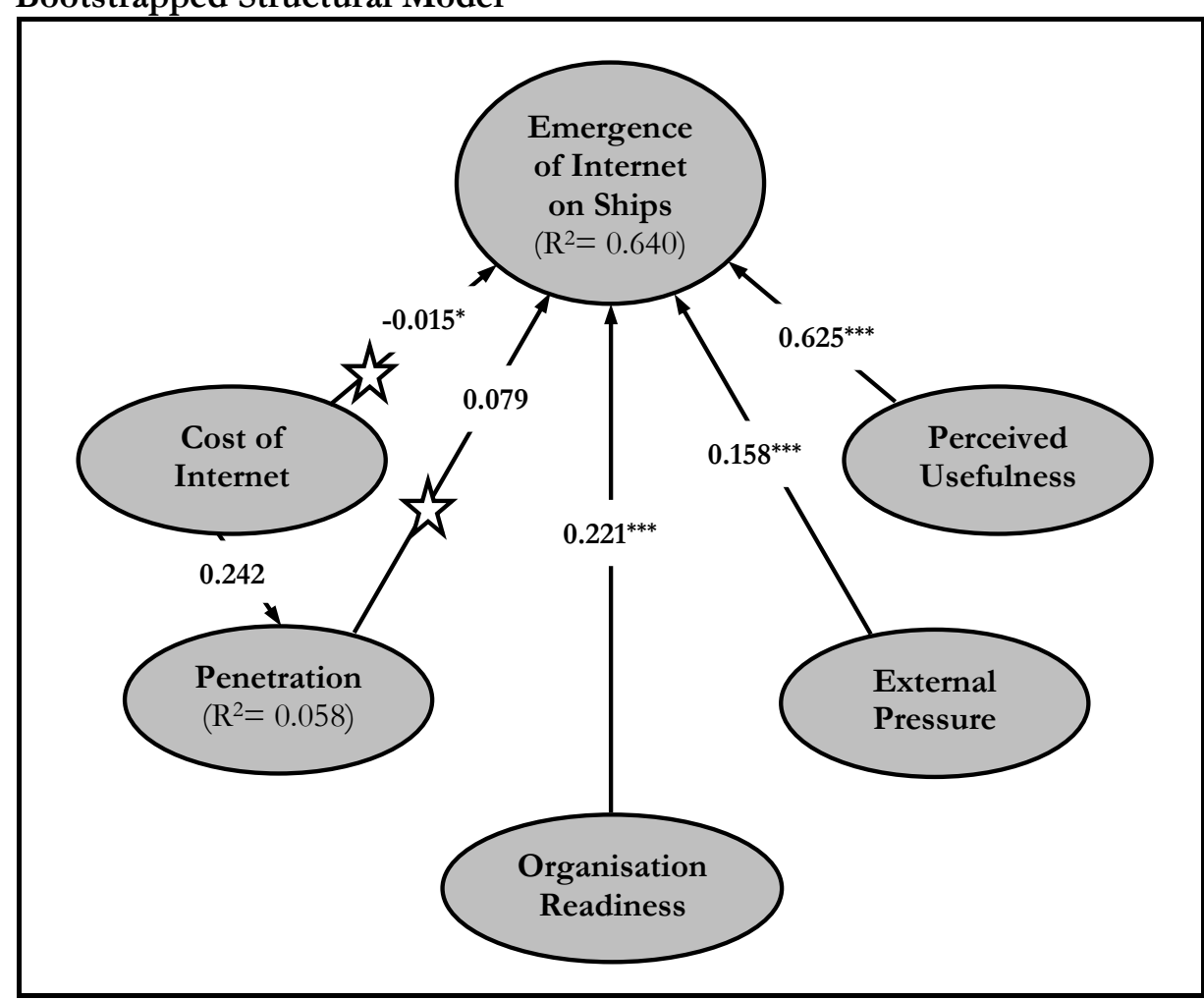




\section{CONCLUSIONS AND CONTRIBUTIONS}

The most obvious and visible uses of the internet have been from the proliferation of e-mail messages and e-commerce sites, but the dependency extends much further (Patel, 2006). Improved multi-mode communication through the Internet is able to provide continuous connection between ship and shore. Access to broadband has become an essential requirement for business success. Operational efficiencies can be mined from various technologies that already exist on board ships, especially with regards to navigating with electronic chart display and information system (ECDIS) since availability of internet on ships ensures that the ECDIS has the latest software on board and effective management of electronic navigation charts (ENC) ensures ships order only those ENCs which are needed for safe navigation. Internet on ships provides data management for Voyage Data Recorder (VDR), which has gained much more emphasis, and right from a near miss to a real incident, the data is available for analysis - internally by the company and externally by competent authorities. There is a lot of vital data that the VDR stores to be deployed by transmitting cheaply through internet connections, for retrieval ashore to analyse and enhance safety and cost efficiency of ship. Access to wide spread data at low costs of satellite communication links between ships and shore creates an efficient mobile dynamic ship reporting systems (Wu et al., 2014). Operational efficiencies demand ship managers use innovations in big data analytics, automation and video streaming, and the key to unlocking this potential is more data exchange between ship-shore-ship, which is possible with the emergence of the Internet on ships. "Internet of things (IoT)" and related "big data" in our maritime industry is thus necessary for the industry to delve deeper and introspect the technologies that surround us which are proving successful with the Emergence of internet on Ships and having a potential to change the way business will be carried out in future (Almonacid \& Franck, 2017). Companies adopting these destructive technologies are expected to benefit and stay ahead of their competitors. More specifically developing an early warning systems for ships through speed communication is perceived to be important to avoid collisions or other perils in the sea (Rao \& Balakrishnan, 2017).

It has taken several years of waiting and innovation in technology for the introduction of the Internet on Ships, which is still at a nascent stage though continuously emerging. This paper tries to highlight the impact of identified key factors i.e. cost, penetration, organisational readiness, external pressure and perceived usefulness, on the emergence of the Internet on ships. The emergence of the Internet on ships provides an effective communication link with all stakeholder of the ship, safety and security is enhanced with real time data on cargo, incidents, piracy, terrorism, weather etc., it also facilitates timely delivery of stores and spare parts for ship repairs and maintenance, thus providing an immense satisfaction to all stakeholders.

\section{LIMITATIONS AND SCOPE FOR FUTURE RESEARCH}

This study focused on the emergence of the internet on ships and the primary data was collected from the shipping industry, mainly from seafarers working on cargo ships. It was also limited to ships already having internet facilities (though in limited form on several ships) hence it may not be a true representation of the emergence of the internet on ships since the majority of cargo ships are still without proper internet facilities. Future research on this topic would bring better results if ships without internet facilities are also included in collecting the primary data as that will present a complete picture at the ground level. The majority of cargo ships responding in this 
study were Tankers, therefore, the scope of research in future studies could be extended to include more types of ships such as containers, car carriers, gas carriers, chemical tankers, passenger ships etc. as that will be a true representation of the shipping industry.

\section{REFERENCES}

Aboelmaged, M. G. (2014, October). Predicting e-readiness at firm-level: An analysis of technological, organizational and environmental (TOE) effects on e-maintenance readiness in manufacturing firms. International Journal of Information Management, 34(5), 639-651.

Addison, T., \& Heshmati, A. (2003, May). The new global determinants of FDI flows to developing countries: The importance of ICT and democratisation. Discussion Paper No. 2003/45, United Nations University (UNU), World Institute for Development Economics Research (Wider).

Almonacid, V., \& Franck, L. (2017, September). Extending the coverage of the internet of things with low-cost nanosatellite networks. Acta Astronautica, 138, 95-101.

Al-Qirim, N. (2007, December). The adoption of eCommerce communications and applications technologies in small businesses in New Zealand. Electronic Commerce Research \& Application, 6(4), 462-473.

Amrutkar, C., Hiltunen, M., Jim, T., Joshi, K., Spatscheck, O., Traynor, P., \& Venkataraman, S. (2013, June 24-27). Why is my smartphone slow? On the fly diagnosis of underperformance on the mobile internet. Paper presented at 43 ${ }^{\text {rd }}$ Annual IEEE/IFIP International Conference on Dependable Systems and Networks (DSN), Budapest, Hungary.

Bacon, D. R., Sauer, P. L., \& Young, M. (1995). Composite reliability in structural equations modeling. Educational \& Psychological Measurement, 55(3), 394-406.

Battisti, G., Hollenstein, H., Stoneman, P., \& Woerter, M. (2007, October 1). Inter and intra firm diffusion of ICT in the United Kingdom (U. K.) and Switzerland $(\mathrm{CH})$ : An internationally comparative study based on firm-level data. Economics of Innovation \& New Technology, 16(8), 669-687.

Beatty, R. C., Shim, J. P., \& Jones, M. C. (2001, July). Factors influencing corporate web site adoption: A time-based assessment. Information \& Management, 38(6), 337354.

Blum, A. (2012, July 16). Mapping the internet. Fortune, 21-27.

Bullmore, E. T., Horwitz, B., Honey, G. D., Brammer, M. J., Williams, S. C. R., \& Sharma, T. (2000, April). How good is good enough in path analysis of MRI data? NeuroImage, 11(4), 289-301.

Chin, W. W. (1998). The partial least squares approach to structural equation modelling. In G. A. Marcoulides (Eds.), Modern methods for business research (pp. 295-358). Mahwah: Lawrence Erlbaum.

Chinn, M. D., \& Fairlie, R. W. (2010). ICT use in the developing world: An analysis of differences in computer and Internet penetration. Review of International Economics, 18(1), 153-167.

Dale, B. (2014, June 30). Internet at sea, a life for me. Fortune.

Davis, F. D., (1989, September). Perceived usefulness, perceived ease of use, and user acceptance of information technology. MIS Quarterly, 319-340.

Dholakia, R. R., \& Kshetri, N. (2004). Factors impacting the adoption of the internet among SMEs. Small Business Economics, 23(4), 311-322. 
Dijkstra, T. K., \& Henseler, J. (2015a, January). Consistent and asymptotically normal PLS estimators for linear structural equations. Computational Statistics \& Data Analysis, 81(1), 10-23.

Dijkstra, T. K., \& Henseler, J. (2015b). Consistent partial least squares path modelling. MIS Quarterly, 39(2), 297-316.

DiMaggio, P., \& Hargittai, E. (2001, Summer). From the 'digital divide' to 'digital inequality': Studying internet use as penetration increases. Center for Arts \& Cultural Policy Studies. Working Paper Series, 15.

Efron, B. (1990). More efficient bootstrap computations. Journal of the American Statistical Association, 85(409), 79-89.

Field, A. M. (2011, January 10). Shaped by the cloud. The Journal of Commerce, 174-175.

Fornell, C., \& Larcker, D. F. (1981). Evaluating structural equation models with unobservable variables and measurement error. Journal of Marketing Research, 18(1), 39-50.

Furrer, O., Tjemkes, B., \& Henseler, J. (2012). A model of response strategies in strategic alliances: A PLS analysis of a circumplex structure. Long Range Planning, 45(5-6), 424-450. http://dx.doi.org/10.1016/j.lrp.2012.10.003.

Gaul Jr., S. E. (2001, October 25). Internet/network security method and system for checking security of a client from a remote facility. U. S. Patent Application 20010034847.

Gefen, Y., Shih, W. H., Laibowitz, R. B., \& Viggiano, J. M. (1987, June 22). Physical Review Letters, 58(25), 2727. http://dx.doi.org/10.1103/physrevlett.58.2727

Gibbs, J. L., \& Kraemer, K. L. (2004). A cross-country investigation of the determinants of scope of e-commerce use: An institutional approach. Electronic Markets, 14(2), 124-137.

Grandon, E. E., \& Pearson, J. M. (2004, December). Electronic commerce adoption: An empirical study of small and medium U.S. businesses. Information \& Management, 42(1), 197-216. Https://doi.org/10.1016/j.im.2003.12.010.

Grover, V., \& Teng, T. C. (1994). Facilitating the implementation of customer-based inter-organizational systems: An empirical analysis of innovation and support factors. Information Systems Journal, 4, 61-89.

Hollenstein, H. (2004). Determinants of the adoption of information and communication technologies (ICT): An empirical analysis based on firm-level data for the Swiss business sector. Structural Change \& Economic Dynamics, 15(3), 315-342.

Hongzhuan, C., Kaifeng, F., \& Zhigeng, F. (2013). Research on complex product cost estimation based on the N-GM $(0, N)$ model. Grey Systems: Theory and Application, 3(1), 46-59. Https://doi.org/10.1108/20439371311293697.

Hsu, P. F., Kraemer, K. L., \& Dunkle, D. (2006). Determinants of e-business use in U. S. firms. International Journal of Electronic Commerce, 10(4), 9-45.

Hutter, M. (2001). Efficiency, viability and the new rules of the internet. European Journal of Law \& Economics, 11(1), 5-22.

Iacovou, C. L., Benbasat, I., \& Dexter, A. S. (1995, December). Electronic data interchange and small organizations: adoption and impact of technology. MIS Quarterly, 19(4), 465-485.

Jaiswal, M. P., \& Raghav, B. (2004, February). Cost-quality based consumer perception analysis of voice over internet protocol (VoIP) in India. Internet Research, 14(1), 95-102 
Kachwamba, M., \& Saebø, Ø. (2012, May). Internet-based information and foreign direct investment (FDI) location decision making: An information cost perspective. African Journal of Business Management, 6(20), 6137-6150.

Kiiski, S., \& Pohjola, M. (2002, June). Cross-country diffusion of the internet. Information Economics \& Policy, 14(2), 297-310.

Kim, J., Lee, I., Lee, Y., \& Choi, B. (2004). Exploring e-business implications of the mobile internet: A cross-national survey of Hong Kong, Japan and Korea. International Journal of Mobile Communication, 2(1), 1-21.

Kuan, K. K. Y., \& Chau, P. Y. K. (2001, October). A perception-based model for EDI adoption in small businesses using a technology-organization-environment framework. Information \& Management, 38(8), 507-521.

Lai, F., Wang, J., Hsieh, C. T., \& Chen, J. C. (2007). On network externalities, ebusiness adoption and information asymmetry. Industrial Management \& Data Systems, 107(5), 728-746.

Lin, H. F., \& Lin, S. M. (2008). Determinants of e-business diffusion: A test of the technology diffusion perspective. Technovation, 28, 135-145.

Lin, J. C. \& Wang N. N. (2013, November 6). Online grey prediction of ship roll motion using variable RBFN. Applied Artificial Intelligence, 27(10), 941-960.

Lu, C. S., Lai, K.-H., \& Cheng, T. C. E. (2006). Adoption of internet services in liner shipping: An empirical study of shippers in Taiwan. Transport Reviews, 26(2), 189206.

Ma, Q., \& Lui, L. (2004, January). The technology acceptance model: A meta-analysis of empirical findings. Journal of Organizational \& End User Computing, 16(1), 59-72.

Mehrtens, J., Cragg, P. B., \& Mills, A. M. (2001, December 20). A model of internet adoption by SMEs. Information \& Management, 39(3), 165-176.

Meinshausen, N., \& Rice, J. (2006). Estimating the proportion of false null hypotheses among a large number of independently tested hypotheses. The Annals of Statistics, 34(1), 373-393.

Nunnally, J. C., \& Bernstein, I. H. (1994), Psychometric theory. New York, N. Y.: McGrawHill.

Nusca, A. (2014). Five surprising reasons ships need internet access. Fortune.

Oliveira, T., \& Martins, M. F. (2010). Understanding e-business adoption across industries in European countries. Industrial Management \& Data Systems, 110(9), 1337-1354.

Patel, P. K. (2006). Estimating the cost of internet service outages: $A$ case study of the methods and factors. Unpublished Doctoral Dissertation, Capella University, Minnepolis, Minnesota. ProQuest Information and Learning Company, UMI Microform 3204909.

Porter, M. E., \& Millar, V. E. (1985, July-August). How information gives you competitive advantage. Harvard Business Review, 63(4), 149-160.

Premkumar, G., Ramamurthy, K., \& Nilakanta, S. (1994). Implementation of electronic data interchange: An innovation diffusion perspective. Journal of Management Information Systems, 11(2), 157-186.

Ramdani, B., Chevers, D., \& Williams, D. A. (2013). SMEs' adoption of enterprise applications: A technology-organisation-environment model. Journal of Small Business \& Enterprise Development, 20(4), 735-753. 
Rao, S. N., \& Balakrishnan, A. (2017, March 22-24). Harnessing low-cost marine internet for collision avoidance of vessels at sea. Paper presented at the International Conference on Wireless Communications, Signal Processing and Networking (WiSPNET) (pp. 2147-2152), Chennai, India. IEEE Computer Society.

Rogers, E. M. (2003). Diffusion of innovations. Simon and Schuster, New York, N. Y.: The Free Press.

Salva, M., Hernandez, R., \& Sanz, C. (2004, January). Proposal of a method for implementing infrared scanning inspection programs in merchant vessels. Marine Technology \& SNAME News, 41(1), 1-6.

Solaymani, S., Sohaili, K., \& Yazdinejad, E. A. (2012). Adoption and use of ecommerce in SMEs. Electronic Commerce Research, 12(3), 249-263.

Son, J. Y., Narasimhan, S., \& Riggins, F. J. (2005, Summer). Effects of relational factors and channel climate on EDI usage in the customer-supplier relationship. Journal of Management Information Systems, 22(1), 321-353.

Steiger, J., Shapiro, A., \& Browne, M. (1985). On the multivariate asymptotic distribution of sequential chi-square statistics. Psychometrika, 50(3), 253-263. http://dx.doi.org/10.1007/bf02294104.

Stein, J. L., Wiedholz, L. M., Bassett, D. S., Weinberger, D. R., Zink, C. F., Mattay, V. S., \& Meyer-Lindenberg, A. (2007, July 1). A validated network of effective amygdala connectivity. Neuroimage 36(3), 736-745.

Szakonyi, M. (2012, October 8). Selling at click speed. The Journal of Commerce, 45-46.

Tian, Z., Liu, F., Li, Z., Malekian, R., \& Xie, Y. (2017). The development of key technologies in applications of vessels connected to the internet. Symmetry, 9(10), 211.

Tirschwell, P. (2004, January 19-25). Demanding, exacting, uncompromising. Retailers raise the bar on logistics performance. The Journal of Commerce, 5(3), 14-17.

Wansink, R., \& Stahl, J. P. (2017). New-generation cable transits accommodate wireless internet modern cable transits for structured cabling systems on cruise ships. SEA TECHNOLOGY, 58(7), 17-18.

Wu, C. Y., Sun, S. Y., Scott, S. C. L., \& Fang, H. J. (2014). User satisfaction toward mobile dynamic ship reporting systems. International Journal of Electronic Business Management, 12(3), 159-166.

Yang, Z., \& Jun, M. (2002, March). Consumer perception of e-service quality: From internet purchaser and non-purchaser perspectives. Journal of Business strategies, 19(1), 19-41.

Yang, Z., Sun, J., Zhang, Y., \& Wang, Y. (2015, April). Understanding SaaS adoption from the perspective of organizational users: A tripod readiness model. Computers in Human Behavior, 45(C), 254-264.

Zhu, K., Kraemer, K., \& Xu, S. (2003). Electronic business adoption by European firms: A cross-country assessment of the facilitators and inhibitors. European Journal of Information Systems, 12, 251-268.

Zikmund, W. (2003). Business research methods. Mason, O. H.: Thomson/South-Western. 